\title{
Potential for Uganda's Input into Global Automotive Supply Chains
}

\author{
James Byansi, Allan Muhumuza, Paul Isaac Musasizi, Sandy Stevens Tickodri Togboa \\ P.O.Box 29905 Kampala (Uganda) \\ Email: [jbyansi, allan.muhumuza, pimusasizi, stogboa]@kiiramotors.com
}

\begin{abstract}
On average, an automobile has over 30,000 parts as it leaves a production line. Most car makers the world over source these parts from global automotive suppliers who form part of the Automotive Industry Value Chain. This paper presents three major sectors where domestic manufacturing can plug into automotive supply chains for parts and components that can be adopted onto the global automotive stage, namely: (1) Materials and Mineral resources; (2) Human Resource Potential; (3) Enterprises already plugging into various aspects of Automotive Manufacturing in Uganda. Uganda is rich with naturally occurring minerals that have generally been exported as raw materials. It is therefore imperative that interventions towards development of capabilities for local processing into viable products that can be absorbed into the automotive markets are achieved. The Ugandan population boasts of highly skilled human resources with institutions producing a skilled labor force that has no opportunities for engagement. It is thus imperative that initiatives take shape to enable local input in the automotive value chain with the ultimate aim of indigenous original equipment manufacturing companies coupled with component and subsystems suppliers to propagate industrialization in Uganda
\end{abstract}

Key words; Local Content, Raw Materials, Local Value Addition, Supply Chains, Mining, Policy, Sustainability

\section{INTRODUCTION}

$\mathrm{T}$ he Uganda Automotive Industry has gone through several shifts since 1885 informed mainly by domestic market forces with very limited policy interventions directed at developing local capacity to plug into global supply chains. The colonial era transport needs and governance structures resulted into growth of a nuclear automotive market with hubs in major regional cities at the time for purposes of administration and resource extraction. The nuclear industry developed in the post-independence era with the emergence of over six SKD assembly plants all located in Kampala for strategic reasons. The decades descending from 1970 were initially founded on the 1970's gross mismanagement of the economy and rapid deterioration of the wider Ugandan Manufacturing Sector resulting into backtracking on earlier interventions for local automotive value addition. Prior to this, the Ugandan market was served with New Vehicles imported mainly from European OEMs. The 1980's saw a total market shift to used vehicles imported as FBUs from Japan with a significantly low acquisition cost. The market has been dominated by these imported second vehicles representing over $85 \%$ of the annual new registrations with Government being the main consumer of Brand New Vehicles.

Several enterprises have emerged and expanded locally with exponentially growing revenue from automotive parts supplies or services. Uganda Revenue Authority and Uganda Bureau of Statistics indicate that 31,200 used and new vehicles were imported into the country in the financial year $2015 / 16$ alone. ${ }^{1}$ It is important to note that this figure only includes pickup trucks, buses, sports utility vehicles (SUVs), Light Duty Trucks (LDTs), and Medium Duty Trucks (MDTs). Despite the small number of complete body unit (CBU) vehicles recorded as traded in the automotive value chain (fig. 1), the few players in this industry have attained wealth and middle income livelihoods stemming from revenues acquired from trading across this value chain.

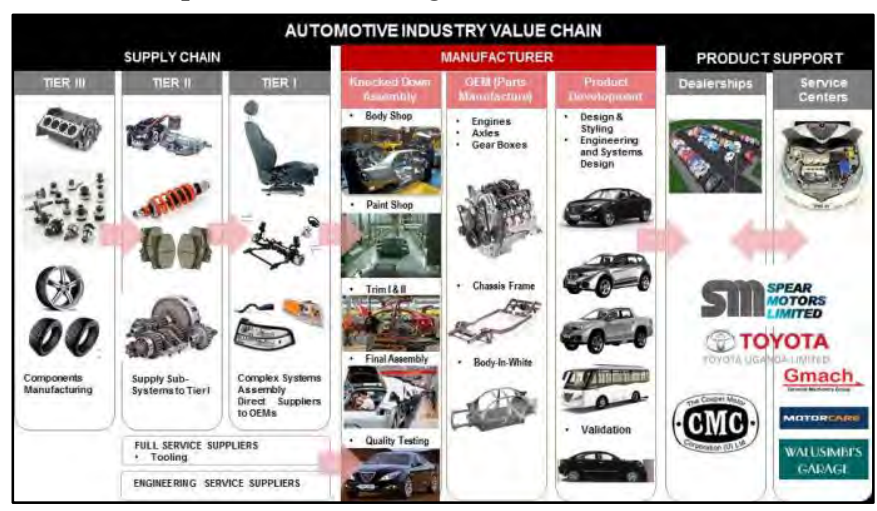

Figure 1: The Automotive Industry Value Chain - Source [2]

The automotive sector still however has a deficit in satisfying the potential to boost the manufacturing sector (fig. 2) by engaging in initiatives that foster a significant boost in the sector.

\footnotetext{
${ }^{1}$ Uganda Revenue Authority (2016) Annual Report 2015-16

2 Kavuma, I. (2015) Kiira Motors Corporation, from a University Extra Curricular Activity to a National Automotive Manufacturing Company
} 


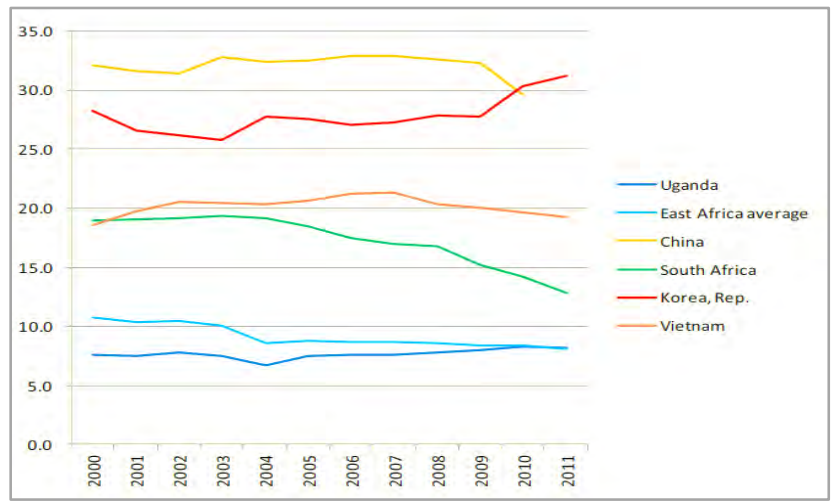

Figure 2: Manufacturing in GDP in Uganda and Selected Countries (\% share), 2000-2011 Source: [3]

As efforts are proliferated towards development of indigenous automotive supply chains, it is important to note that an automobile has over 30,000 parts with components sourced from global automotive suppliers.

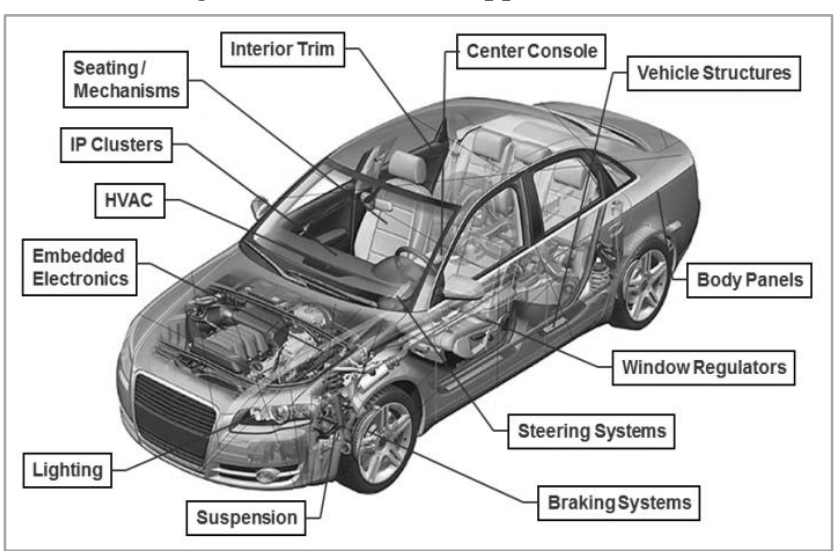

Fig1: Summary of passenger car systems, Source [4]

In countries like Singapore where there has been an influx of global suppliers sourcing for locally manufactured components due to abundance of raw materials and using the local manufacturing infrastructure to produce components that are locally validated for global standards to eventually make up the bulk of the national contribution to GDP due to high profitability of the parts acquired in the automotive sector. Uganda does not fall shy of abundance of naturally occurring raw materials that can effectively adopt the same model for local value addition and greatly boost local manufacturing.

\section{RAW MATERIALS NATURALLY OCCURRING IN UGANDA.}

Uganda lies within the African plate which is a continental crust that contains Achaean crotons that date at least 2700 $\mathrm{Ma}$ (Ma is a geological symbol meaning millions of years before the present age) [5] Currently, the country produces a

\footnotetext{
3 Eastern Africa's Manufacturing Sector - Uganda Country Report - World Bank/World Development Indicators November 2014.

${ }^{4} \mathrm{http} / / / \mathrm{www}$.intent-design.com/automotive-and-transportation $\quad$ (Accessed $29^{\text {th }}$ September 2017)

5 Naigaga, E. (2014) An Analysis of the Policy Framework for the Mining Sector in Uganda. Int'1 Journal Of Research In Chemical, Metallurgical and Civil Eng. Vol. 1, Issue 1
}

number of minerals valued at almost UGX.100 billion per annum. Minerals including gold, tin, gemstones, limestone, clay, salt and stone aggregate are mined. The mining industry in Uganda reached peak levels in the 1950's and 1960 's when the sector accounted for up to $30 \%$ of Uganda's export earnings. However, political and economic instability experienced in the country in the 1970's and the recent global economic slowdown led the sector to decline drastically. Uganda currently produces a number of minerals valued at almost UGX.100 billion. However, the sector is regulated by four main bodies which generally lack coordination thus affecting the entire mining sector, rendering the laws and policies un-sustainable." [6]

Even the tiniest vehicle observed on the road has up to one ton of steel whose raw materials are iron ore that is naturally occurring in Uganda. Plastic is the second most prominent material on the automobile those raw materials are Oil and Gas for which deposits of over 2.5 Billion barrels were in 2006 discovered by Hardman Resources of Australia in Warangal and Mputa - Western Uganda. [7]

Lead is another mineral that exists in Uganda today, which is an important component of normal car batteries. However, as the world moves away from internal combustion engines to electric cars, graphite, a key ingredient in lithium Ion Batteries has been observed to be naturally occurring in ZeuNebbi, Matidi \& Acholibur - Kitgum District. Deposits of lithium itself have been discovered in Central and western Uganda.

Cotton is a key input to car upholstery and interior padding; it goes without mentioning that Uganda grows cotton and can even supply more of it to the global automotive value chain. The Cotton Development Organization (CDO), which oversees cotton production in Uganda, says that the rain-fed crop can be produced in most parts of Uganda. It is mainly grown in north, east \& south east of Lake Kyoga, and in the Kasese area in the western part of the country. Fabric used on car seats, side panels, ceilings and carpeting.

Glass naturally occurs as silica or sand. Many deposits of sand and silica are naturally occurring in several parts of the country. They have been mainly discovered on the shores of Lake Victoria near Ddimo landing site in Bukoto Central constituency, Masaka district.

There is a wide array of raw materials naturally occurring in Uganda. With major shifts towards capabilities for local manufacturing, there is great potential for supply of components onto global automotive supply chains coming from Ugandan Industries.

\footnotetext{
${ }^{6}$ Thomashausen, S (2003) Comments on Uganda's Mining Act and

Regulations, Columbia law school and the earth institute.

${ }^{7}$ Cassie, B (2016) Discovering Oil in Uganda: Opening the East African Rift Play
} 


\section{The leather Industry}

There have been several initiatives to boost local value addition in the leather industry. This has however been met with several setbacks and has not lived up to the projected growth potential that had been envisaged for the leather industry in Uganda. Hides and skins, the raw materials for leather, are byproducts of the meat industry as well as fish and crocodiles. If the hide or skin is processed into leather its multiplier effect is three or four times, and in finished products ten or twelve times, more profitable than if sold in its raw form. Finished leather is used for the manufacture of footwear, bags, upholstery, belts, wallets, and accessories used in textile and basketry industries. For the case of the automotive industry, it is used for Interior upholstery from dash boards, arm rests, seats and back covers. Uganda has favorable climatic conditions that are well suited for animal husbandry which is the main source of leather

The key initiatives for growing the leather industry in Uganda include:

\begin{tabular}{|c|c|}
\hline Institution & Purpose \\
\hline $\begin{array}{l}\text { National Leather and } \\
\text { Leather Products } \\
\text { Policy; }\end{array}$ & $\begin{array}{l}>\text { This policy devised in } 2015 \text { advocates for a } \\
\text { dynamic and competitive leather subsector } \\
\text { through maximization of value addition } \\
\text { and cleaner technologies. } \\
>\text { Government has put in place fiscal policies } \\
\text { and regulations to boost supply of hides } \\
\text { and skins to the local tanneries by } \\
\text { discouraging export of raw materials. } \\
>\text { As a result the number of tanneries } \\
\text { increasing from four in } 2010 \text { to seven in } \\
\text { 2014. }\end{array}$ \\
\hline $\begin{array}{l}\text { COMESA Leather } \\
\text { and Leather Products } \\
\text { Institute } \\
\text { (COMESA/LLPI) }\end{array}$ & $\begin{array}{l}\text { This establishment advocates a holistic } \\
\text { transformation of the leather industry with } \\
\text { statutes and legal framework instruments } \\
\text { geared towards development of local } \\
\text { capacity for value addition and } \\
\text { implementation of these frame works. }\end{array}$ \\
\hline $\begin{array}{l}\text { Uganda Leather and } \\
\text { allied industries } \\
\text { association } \\
\text { manufacturers } \\
\text { association. }\end{array}$ & $\begin{array}{l}\text { Advocates for Value addition in leather } \\
\text { processing in Uganda given that the hides } \\
\text { and skins are only processed up to wet- } \\
\text { blue level. }\end{array}$ \\
\hline $\begin{array}{l}\text { Uganda small Scale } \\
\text { Industries } \\
\text { Association; }\end{array}$ & $\begin{array}{l}\text { The Uganda Small scale industry } \\
\text { association has initiated efforts to avail } \\
\text { opportunities for local players in leather } \\
\text { processing to scale up their production to } \\
\text { grades and standards that can supply local } \\
\text { and foreign markets. }\end{array}$ \\
\hline
\end{tabular}

Source; Multiple sources.

The leather industry is challenged my four major hindrances to flourish which are; Smuggling, Importation of low-quality and low-cost leather products, High cost of doing business and lack of gazette abattoirs. The steel industry is dominated by iron monger and recycling where there are no stamping facilities in Uganda.

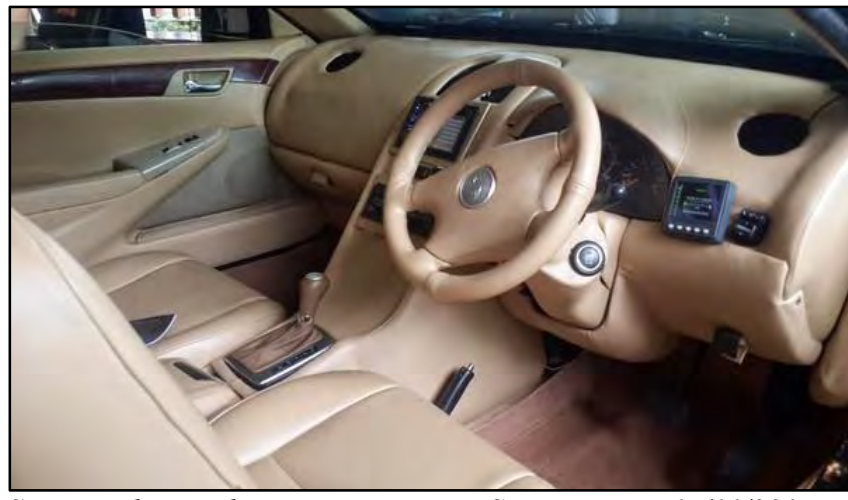

Source: Photo Taken at Kiira Motors Corporation - 14/11/2017

\section{SWOT analysis}

Strengths Institutions are or have been set up for standards and quality in the industry

The meat policy and the hides, skins and leather development policies have been developed

Skinners and flayers are being trained to reduce flay cuts Trained footwear and leather goods entrepreneurs and workers available.

\begin{tabular}{ll}
\hline Weaknesses & Lack of trade and marketing information; low productivity \\
& and poor workmanship; lack of grading law hides and skins \\
& and price settings; lack of commercialized farming systems; \\
& poor marketing
\end{tabular}

Opportunities Uganda's hides and skins are naturally of high quality, high texture and heavy substance.

Uganda has many water bodies which provide a large quantity of fish and, in addition, the government has encouraged fish farming in many areas, consequently a high potential for fish skin.

Crocodile farming in Uganda is gaining popularity for the provision of the valuable crocodile skin and this provides great potential for investment.

Supportive and complementing government programs in the areas of livestock health and production as well as infrastructure development.

Local demand for leather and leather products shows an upward trend.

Bilateral and multilateral trade arrangements such as East African Customs Union, Common Market for Eastern and Southern Africa (COMESA), African Growth Opportunity Act (AGOA), African Caribbean and Pacific European Union (ACP-EU) and COTONOU agreement, provide potential regional market for finished leather and leather products.

Threats Institutional weakness; Lack of a policy to guide the sector to address the constraints and amend the Hides and Skins trade Act of 1964 which does not conform to the new policy reforms.

Poor production methods associated with lack of proper equipment, inadequate infrastructure, limited human resource capacity and poor husbandry practices.

Limited processing and value addition due to lack of quality raw materials, inadequate human resource, environmental concerns, high investment costs and lack of incentives to invest in the industry.

Poor marketing as a result of poor quality products, competition from second hand and synthetic goods, poor infrastructure and marketing information, lack of credit facilities, subsidies and protectionist policies in foreign markets.

Low participation of women due to limited awareness, cultural hindrances and limited access to means of production and resources. 


\section{Table1: Minerals relevant to automotive production naturally occurring in Uganda}

\section{Multiple sources [8], [9]}

\section{Mineral and location(s)}

Copper

Kilembe in Kasese District, Boboong in

Kotido District; Kitaka in Bushenyi

\section{Cobalt}

Kilembe in Kasese Distric

\section{Chromite}

Nakiloro in Moroto District

\section{Gold}

Districts of: Bushenyi, Mbarara, Kabale

Kisoro, Rukungiri Kanungu, Busia,

Mubende, Moroto, Hoima, \& many streams of West Nile
District; Kampono in Mbarara District

\section{Application in the automotive industry}

Copper plays a critical role in cars for functionality, efficiency, comfort and safety. It is mostly used to carry data, sending control signals and supply electrical power. The total weight of copper in a vehicle ranges from 15 kilos for a small car to 28 kilos for a luxury car

The battery industry currently uses 42 percent of global cobalt production, a critical metal for Lithium-ion cells

Many of the decorations on automobiles, such as ornaments, trim, and hubcaps, are chromium plated. Chromium in super alloys (high-performance alloys) permits jet engines to operate in a high-temperature, high-stress, chemically oxidizing environment. Chromium pigments are used to make the yellow lines that indicate traffic lanes

Automotive gold plating enhances the appearance of exterior parts, such as emblems, hood ornaments, door handles and wheel rims and is offered by some car dealers as an aftermarket service for car owners who wish to enhance the style of their vehicles. Gold plating will also make these exterior parts much more resistant to corrosion and wear. Gold plating is also used to improve the electrical conductivity of electronic parts and components.

Steel, produced from mined iron ore, the base raw material, is perhaps the most widely used component in auto manufacturing. It accounts for roughly $80 \%$ of the weight of an average car. Steel is used to construct a car's chassis and body, including the roof, body and door panels, and the beams between doors.

,

Mbarara, \& Hoima Tororo (Magnetite in

Bukusu and; Sukulu), Moroto (Napak) \&

Kotido (Toror)

Recent discoveries are in Bufumbira

County, Kisoro, Nangara, Karukara,

Buhara in Kabale District, Butogota in

Kanungu District \& Kateera in Mityana.

Lead

Kamwenge District (Kampono,

Kanyambogo and Kitaka in Kitom

Forest), Isingiro district (Kikagati)

Lithium

Ruhuma in Kabale District; Mwerasandu,

Rwamwire and Nyabushenyi in Ntungamo

District; Lunya in Mukono District

Nampeyo and Mbale Estate in Mubende

District.

\section{Columbite/ tantalite}

Ntungamo District; Bushenyi District;

Kanungu District; Kisoro district and Lunya in Mukono District, Sukulu in Tororo District, Bukusu Complex in Mbale District; Napak in Moroto District and Tororo in Kotido District.

Tin

Mwerasandu, Kaina, Nyinamaherere in Ntungamo District; Kikagati in Isingiro District, Ndaniyankoko, Kitezo in Mbarara District, Burama Ridge on the Kabale/ Ntungamo border, Rwaminyinya in Kisoro District.

Titanium

Bukusu Complex in Manafwa Distric $(22 \% \mathrm{TiO} 2)$ and Sukulu in Tororo District (13\% TiO2).

Zinc

Zinc occurs with galena at Kitaka in Kamwenge District

\section{Kaolin}

Namasera, Migadde and Buwambo in Wakiso district; Mutaka in Busheny District, Kisai in Rakai District and Kilembe in Kasese District

\section{Glass/sand}

Diimu and Bukakata in Masaka District; Lwera in Masaka District, Nalumuli Bay,

Nyimu Bay and Kome Island in Mukono

District

Lead is used in a number of car components, including lead wheel weights, solder in electronics, and lead car batteries.
Lithium is a good choice for an electrochemical cell due to its large standard electrode potential $(-3.04 \mathrm{~V})$ resulting in a high operating voltage (which helps both power and energy) and the fact that it is the metal with the lowest density (which reduces weight).

Niobium reduces weight of a car by $200 \mathrm{~kg}$ and increases fuel efficiency by $5 \%$

Over $90 \%$ of world production of tinplate is used for containers (tin cans).... and weather sealing material and in construction of automotive gasoline tanks

Valve springs can be easily produced from titanium and are widely used in racing. When combined with conventional steel valves, a weight reduction of around $40 \%$ can be attained. Titanium valve cups are also used in car racing. Automotive manufacturing applications for zinc and zincnickel plating include: Engine and other under-the-hood components, Power steering systems, Brake parts and systems, Air-conditioning components and systems, Chassis hardware, Climate control components, Fuel systems

Kaolin plays an important role in the manufacture of automotive primers by providing tank stability, film smoothness, corrosion resistance, edge film build and uniformity.

Wind screens, mirrors and rear windows.

\section{Status of reserves \& Nature of progress of actio}

Reserve at closure was about 6 million tons at $1.77 \% \mathrm{Cu}$; (ii) Grade of $1.7 \%$ at Boboong; and Reserves at Kitaka and Kampono are under evaluation

$>$ Government signed concession agreement with a Chinese company Tibet Hima to develop the copper resources at Kilembe mines. Reserves at Kitaka and Kampono are under exploration.

5.5 Million tons with grade of 0.17 of cobalt Kasese Cobalt Company Limited has been processing cobalt stockpile, which is nearly exhausted.

Under evaluation \& Under Exploration

Five (5) million ounces of gold in Mubende District by Anglo Uganda Corporation; (ii) One (1) million ounces of gold estimated at Mashonga;(iii) 500,000 ounces of gold estimated at Tiira, Busia; and (iv) Over 500,000 ounces estimated at Alupe in Busia. (v) 139,000 ounces and possible reserves of 160,000 of gold at Nakabat in Moroto District.

> Mining Leases Granted to: 1. M/s Greenstone resources at (Tiira, Busia District); 2. M/s Anglo Uganda Corporation (AUC Mining, Mubende District); 3. M/s Kisita Co. Mining (Mubende District) and

$>\mathrm{M} / \mathrm{s}$ Jan Mangal (U) Limited in Moroto District

$50 \mathrm{Mt}$ at Muko, Kabale; (ii) $2 \mathrm{Mt}$ in Mugabuzi, Mbarara; (iii) $23 \mathrm{Mt}$ at Bukusu and $45 \mathrm{Mt}$ at Sukulu; Tororo District; (iv) $48 \mathrm{Mt}$ at Buhara in Kabale District (new discovery); (v) $55 \mathrm{Mt}$ at Butogota in Kanungu District (new discovery); (vi) 8 million tons in Bufumbira, Kisoro (new discovery)

> Four (4) Mining Leases, granted for development of iron ore resources: Great Lakes Iron \& Steel Company Limited, Kigez Steel Company Limited, Uganda, Uganda International Mining Company Limited and Sino Minerals

Under Evaluation

Under Evaluation though Pegmatite deposits suitable for small scale mining

> 130 million tons of Niobium at Sukulu

3.5 million tons of columbite-tantalite estimated at Kagango in Ntungamo district.

$>$ The Sukulu phosphate deposit is potentially the most important source of Niobium.

1.0 million tons at $2.5 \%$ tin estimated in Ntungamo and 2.5 million in Isingiro by First Mining Company Limited Underdeveloped.

$>$ Two mining leases have been granted to; Zarnack holdings; and First Mining company Limited

Grade of titanium is $22 \% \mathrm{TiO} 2$ and $(13 \% \mathrm{TiO} 2$ in Bukusu and Sukulu respectively.

$>$ Under Evaluation

2.8 million tonnes at Mutaka, Bushenyi, One (1) million tonnes at Kisai(Koki), Rakai

On demand by local industrial sector

The highest quality $99.95 \% \mathrm{SiO} 2$ at Kome islands, Mt at Dimu and Bukakata $(99.93 \% \mathrm{SiO} 2)$

$>$ It is a viable investment

8 Yager, R. (2016) The Mineral Industry of Uganda, U.S. Department of the Interior, U.S. Geological Survey

${ }^{9}$ Https://Www.Quora.Com/What-Natural-Resources-Are-Used-In-Cars (accessed 30 ${ }^{\text {th }}$ September 2017) 


\section{Human resource potential}

It is estimated that currently the Ugandan economy needs to absorb about 392,000 new entrants into the labor market (Ministry of Gender, labor and Social Development 2010). The labor force growth rate is estimated at 4.7 per annum in $2009 / 10$ a rate which is even higher than the population growth rate. The growth in the youth labor force is even much higher estimated at 5.7 percent annually. The economy will 5 also need to generate many jobs for the rapidly expanding labor force, in order to exploit the potential benefits of the window of opportunity [10]

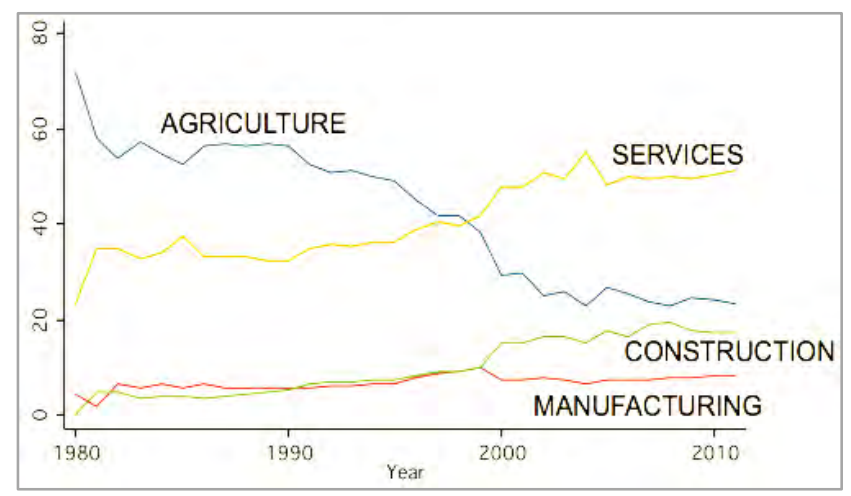

Figure 3: Percentage of contributions in GDP per sector. 1980-2011 Source: [11]

\section{Tertiary and technical training institutions}

There are a number of training institutions in Uganda specifically offering hands on and theory in the automotive space. There is also a number of specialized automotive workshops and training institutions in Uganda.

\begin{tabular}{|c|c|c|}
\hline No. & Institution & Program \& Duration \\
\hline 1 & Makerere University & $\begin{array}{l}\text { Bachelor of mechanical engineering } \\
\text { Bachelor of electrical engineering } \\
\text { (Electrics and Electronics, Systems } \\
\text { Design) 4yrs }\end{array}$ \\
\hline 2 & Kyambogo University & $\begin{array}{l}\text { Bachelor of Engineering in } \\
\text { Automotive \& Power Engineering } \\
4 \text { yrs }\end{array}$ \\
\hline 3 & $\begin{array}{l}\text { Uganda Technical } \\
\text { College - Elgon }\end{array}$ & $\begin{array}{l}\text { Diploma in Mechanical Engineering } \\
2 \mathrm{yrs}\end{array}$ \\
\hline 4 & $\begin{array}{l}\text { Uganda Technical } \\
\text { College - Lira }\end{array}$ & $\begin{array}{l}\text { Diploma in Mechanical Engineering } \\
2 \text { yrs }\end{array}$ \\
\hline 5 & $\begin{array}{l}\text { Church of Uganda } \\
\text { vocational training } \\
\text { school, Soroti }\end{array}$ & $\begin{array}{l}\text { Motor Vehicle technician's course } 4 \\
\text { yrs. }\end{array}$ \\
\hline 6 & $\begin{array}{l}\text { Uganda Technical } \\
\text { College - Elgon }\end{array}$ & $\begin{array}{l}\text { Diploma in Mechanical Engineering } \\
2 \mathrm{yrs}\end{array}$ \\
\hline 7 & $\begin{array}{l}\text { Uganda Technical } \\
\text { College - Lira }\end{array}$ & $\begin{array}{l}\text { Diploma in Mechanical Engineering } \\
2 \text { yrs. }\end{array}$ \\
\hline 8 & $\begin{array}{l}\text { St joseph's technical } \\
\text { college Kisubi }\end{array}$ & Motor Vehicle Technician 2yrs \\
\hline 9 & $\begin{array}{l}\text { Copper Motors training } \\
\text { center }\end{array}$ & Apprenticeship training \\
\hline 10 & $\begin{array}{l}\text { Nakawa Vocational } \\
\text { Training center }\end{array}$ & Apprenticeship training \\
\hline
\end{tabular}

10 Haussmann, R (2014) How should Uganda grow? Kennedy School, Harvard University

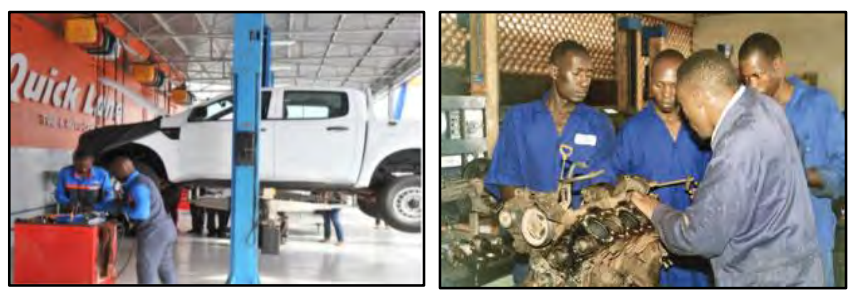

CMC Quick Lane Tyre and auto center mechanics servicing a vehicle. Trainees at Nakawa Vocational Training Institute.

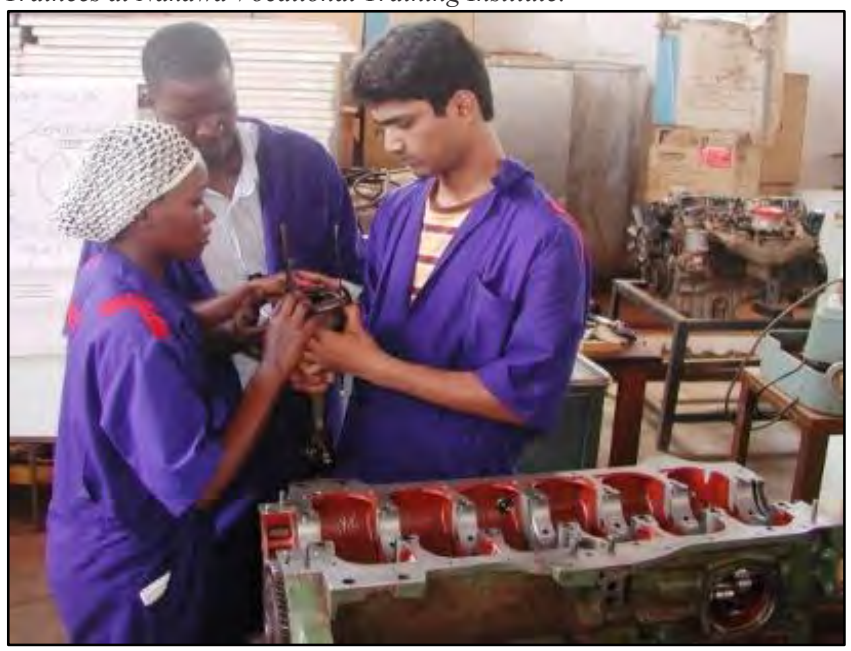

Trainees at the Spear Motors Training and apprenticeship center

The Majority of garages within urban centers in Uganda also offer informal training by way of apprenticeship in automotive repair. There are other inputs like industrial design in automotive development which are not prominent in the region though over the years, talent has been sought by major OEMs from Africa case in point being General Motors Lead Exterior Designer- Nigerian born Jelani Aliyu. [12]. Institutions training in this area are offered by the following institutions; Margaret trowel school of industrial and fine arts, Artfield institute of design, Uganda Industrial research institute, Michael Angelo Institute of Design, \& Design School of Kampala University.

\section{LOCAL VALUE ADDITON ENTERPRISES}

\section{Body shops and panel beaters}

There is evidence of earlier attempts at building car bodies in Uganda, the most prominent coach builder hail from the suburbs of Katwe exhibiting the capacity to repair and also modify carriage wagons as the entry point to value addition on car bodies. Body shops and panel beaters

The stabilized political environment saw forth the emergence of local crafts men manufacturing though on a small scale spare parts and reconditioning of vehicle components. Vehicle canopies for pick-ups at Henkel Polymer Company Limited and Multiple Industries Limited cost between $650-1000$ USD. Both companies are local initiatives for fibre glass and plastic products.

Fibre glass component manufacturers are also active participants in the automotive industry value chain. Key companies that are prominent in this regard are:

\section{Musa Body Group;}

Point of entry was making wooden car bodies this enterprise has more recently gained prominence from fabricating a car 
and naming it "Uganda 1", Everything on this car was made in Katwe except the engine Tyres and glass works.
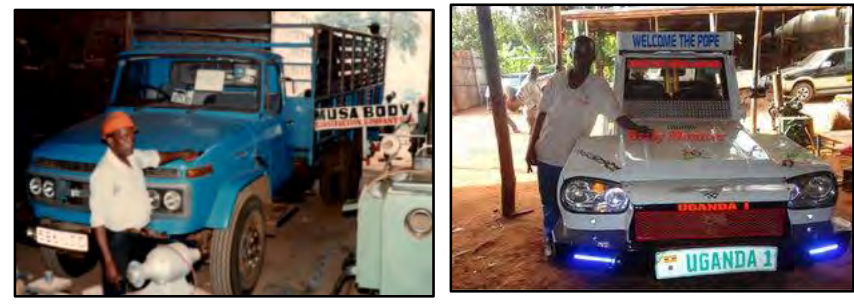

Figure 8; A lorry carriage body and the Uganda 1 car made by Musa Body Engineering Inc.

Source; https://musabodyfoundation.files. - Kasifa Nabatanzi

\section{Makerere Body modification workshop}

There has been an extension of services by auto repair workshops, the most commercially viable thus far is Godfrey Namunye's body modification workshop where ordinary vehicles are modified for on average USD 3,000 fiber glass in the core material used to build onto or repair the car bodies. The clientele ranges from local celebrities, pastors and socialites in Uganda.
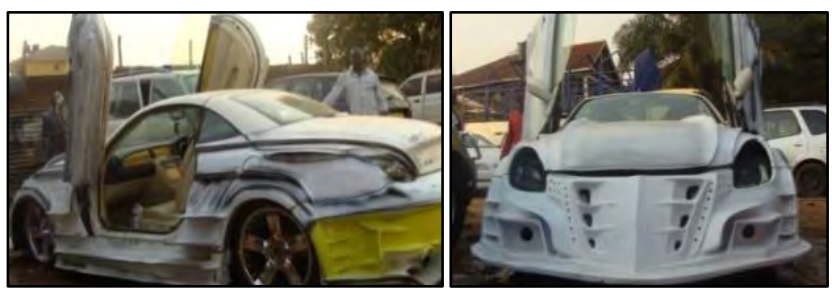

Figure 10; Godfrey Namunye's Body modification workshop at Makerere Kavule

Source; http://www.bbc.com/news/world-africa-26297365

\section{Rubaga bus body builders}

Bus body builders mainly starting out as repair workshops are seen to emerge among workshops in Rubaga; local crafts men with training from bus building plants in Nairobi have trickled into the industry mainly due to cost comparisons with having to transport buses to Nairobi for body repair works. The bulk of works done in Rubaga is refurbishment.

\section{Jussy Coaches and Pro-Ride}

There key output is SUVS modification for recreational vehicles.

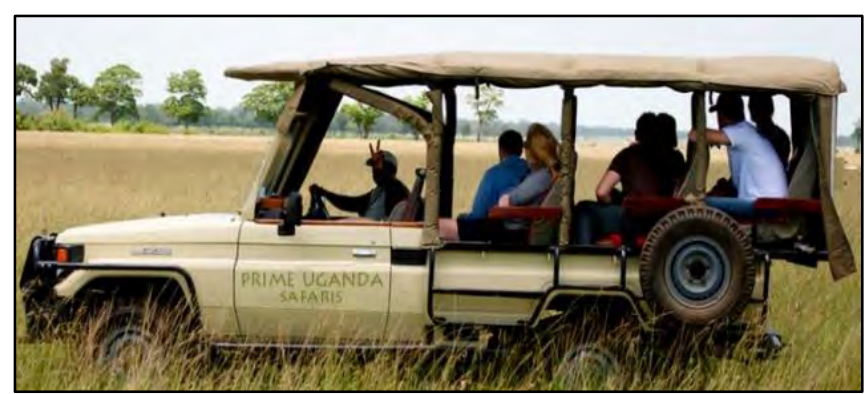

Figure 10; A tourist vehicle with body modifications done locally from a 1998 Toyota land cruiser.

Source; prime safaris.com, Monitor.co.ug

\section{Interior upholstery}

This is one of the most applied interventions since there is relatively high demand for transformation of service vans into passenger mini vans that are the main form of public transport in Uganda.
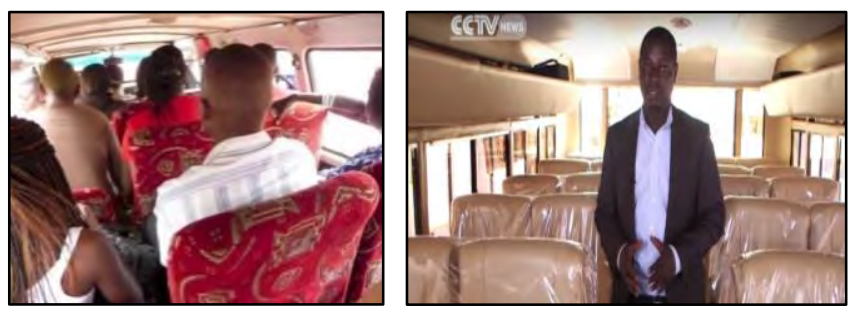

Figure 11; L-a service van transformed into a Passenger service vehicle in Kampala city. R- a locally crafted Kayoola solr bus interior by kibuli Fabricators Source; Multiple sources

\section{Innovation from educational institutions} Vehicle Design Project, Makerere University.

The vehicle design project at Makerere University produced the first electric car made in Africa.

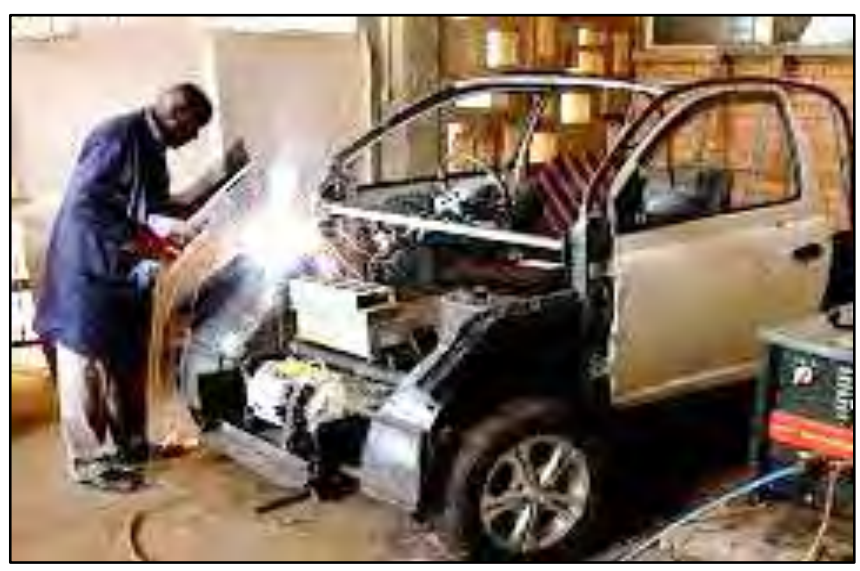

Fabrication of the Kiira EV at CEDAT-Makerere University Source; Multiple Sources

\section{The MV Mulimi}

Mechanized agriculture remains a focal development goal and initiatives from agricultural engineering students at the Makerere University Institute of Agricultural Research brought forth the MV Mulimi innovation in January 2016

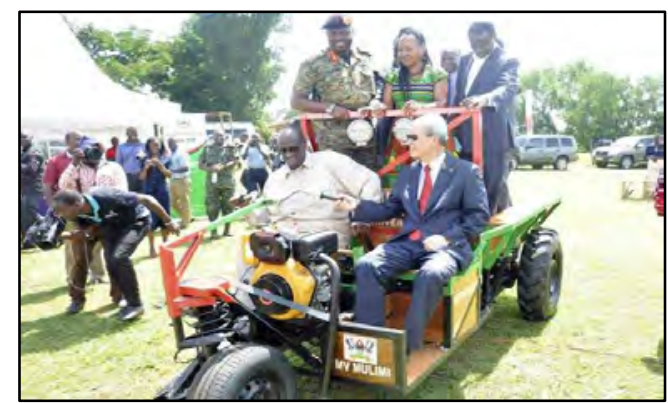

Gen. Khaleb Akandwanaho (L) \& Chinese Ambassador Zhao Yali test drive the MV Mulimi

\section{The Kyambogo University Biofuels Vehicle}

In 2014 Kyambogo University Department of Mechanical Engineering exhibited a Vehicle converted from traditional focil fuels to Ethanol-Based Bio-Fuels a major milestone in Bio Fuels for Mobility Research a part of the prospected alternative energy for mobility initiatives in Uganda. 


\section{Recommendations}

i. Homologation certification and standards; UNBS must formulate a subs-section dedicated to certification of automotive components so as to have local suppliers whose output plugs into international supply chains.

ii. A phased tariff program for complete body units and on used vehicles coupled with import substitution correlated with higher local production volumes to satisfy local market demand but also extending markets for a wider reach namely the EAC and COMESA.

iii. The Buy Uganda Build Uganda Initiative that has been fast tracked to enable local sourcing of services and consumables shall go a long way in ensuring that there is total consideration of Ugandan components in the automotive supply chain

iv. Reinforcement of training institutions to enhance direct application of knowledge in industry, this shall be coupled with an influx of trainers that have been exposed to advanced automotive markets with knowledge that can impart skills development in the local nascent auto industry.

v. Government support (Incentive) schemes such as Duty Free Allowance, Export Based schemes to encourage export promotion and Small Vehicle Incentives to encourage the consumption of vehicles locally, the Taxi exchange program is a case in point.

vi. State owned indigenous automotive corporations should be a national priority where Transnational Auto Monopolies are, incentivized to adopt locally manufactured components in their supply chains and as such not only supply local assemblers but also integrate in their international supply chains.

vii. OEM representation in regulatory bodies where institutions like UNBS, URBS, and IRA should have contributions from OEMs so as to harmonize operational requirements directly with policies that should drive greater productivity among the OEMs but with the consumer protection in mind.

viii. Licensing agreements and joint ventures to fast track technology transfer and propagation of geographical licensing of intellectual property.

ix. Power, Infrastructure, Technology \& Domestic Industrial infrastructure development, in particular supplier parks and clusters. To provide an environment where small scale industries can step up and standardize there operations so as to fit requirements in automotive supply chains.

x. Skills development and training must be responsive to technical requirements in the automotive manufacturing sector. A specialized automotive training academy fully state owned and operated should be put in place.

xi. Investment promotion, including fiscal measures in supplier parks and free trade zones for component manufacturers can only be fostered by government through its operational arms like UIA, Free Trade Zones Authority and Export Promotion Board.

\section{Acknowledgements}

The Authors extend gratitude to the management and staff of Uganda Development Corporation, Kiira Motors Corporation and the Ministry of trade, Industry \& Corporatives.

\section{REFERENCES}

[1] Uganda Revenue Authority (2016) Annual Report 2015-16

[2] Kavuma, I. (2015) Kiira Motors Corporation, from a University Extra Curricular Activity to a National Automotive Manufacturing Company

[3] Eastern Africa's Manufacturing Sector - Uganda Country Report - World Bank/World Development Indicators November 2014.

[4] http://www.intent-design.com/automotive-andtransportation (Accessed $29^{\text {th }}$ September 2017)

[5] Naigaga, E. (2014) An Analysis of the Policy Framework for the Mining Sector in Uganda. Int'l Journal Of Research In Chemical, Metallurgical and Civil Eng. Vol. 1, Issue 1

[6] Thomashausen, S (2003) Comments on Uganda's Mining Act and Regulations, Columbia law school and the earth institute.

[7] Cassie, B (2016) Discovering Oil in Uganda: Opening the East African Rift Play

[8] Yager, R. (2016) The Mineral Industry of Uganda, U.S. Department of the Interior, U.S. Geological Survey

[9] Https://Www.Quora.Com/What-NaturalResources-Are-Used-In-Cars (accessed $30^{\text {th }}$ September 2017)

[10] Haussmann, R (2014) How should Uganda grow? Kennedy School, Harvard University 